\title{
After Austerity: Welfare State Transformation in Europe after the Great Recession
}

\author{
POR João Monteiro* \\ * Membro Associado do Observatório Político, Portugal
}

\author{
Taylor-Gooby, P., Leruth, B. \& Chung, H. (Eds.) (2017). \\ After Austerity: Welfare State Transformation \\ in Europe after the Great Recession. \\ Oxford: Oxford University Press
}

I.

\begin{abstract}
"Challenging times are as likely to widen the scope for progressive welfare state building as they are to diminish it, and how states respond is a matter of political struggle and political choice."
\end{abstract}

(Farnsworth and Irving, 2011 cited in Harst and Rakar, 2017)

Edited by Peter Taylor-Gooby, Benjamin Leruth and Heejung Chung, After Austerity: welfare state transformation in Europe after the great recession is a collective endeavour that aims to research the welfare state transformation in Europe and the future new directions in social policy. The transformation of the welfare states in Europe since the 1970s has been driven by complex interacting economic, social and political pressures, operating at different speeds in different national, historical and institutional contexts (Taylor-Gooby, Leruth and Chung, 2017, pp.1-7). These economic pressures (global competition, technological change, transitioning from a predominantly manufacturing to a predominantly service economy, dualization of market between high-skilled and low-skilled labour), social pressures (demographic ageing, changes in gender roles and family patterns, increase in immigration) and political pressures (weakening of the traditional political organisation of the working class and emergence of neo-liberal individualism) all led to the disruption of the traditional welfare state. Furthermore, they have been compounded by two more recent exogenous factors, namely the Great Recession of 2007-2009 and increasing 
immigration (Taylor-Gooby, Leruth and Chung, 2017, p.202). An important point, however, is that the operation of the various long- and short-term pressures in the national context are mediated by political factors which differ between countries and have an influence in the direction of the welfare state development (Taylor-Gooby, Leruth and Chung, 2017, p.17).

In face of these pressures, the book puts forward three hypothesis for the future social policy directions of welfare states, namely if they develop some sort of convergent, divergent or parallel policy pattern (Taylor-Gooby, Leruth and Chung, 2017, pp. 14-17). Convergence theories suggest that similarities in context and structure between welfare states will lead them to develop towards a common model. Theories of structured diversity argue that real differences will be sustained over time, enabling us to group countries as in regime theory or varieties of capitalism. Beyond continuity theories suggest that similar pressures between countries differ in the way they are managed and, therefore, national policy directions might make it impossible to frame a single pattern of response.

In order to test the hypothesis of convergence or divergence between regimes, seven types of policy responses will be considered (Taylor-Gooby, Leruth and Chung, 2017, pp. 11-14). These responses are austerity (cutbacks and privatisation), individualisation of responsibility (privatisation and means-testing benefits), interventionism (counter-cyclical policies), social investment (investment in human capital and family support), predistribution (maintenance of market incomes and control of prices through regulation), fightback (anti-austerity measures) and welfare chauvinism (restriction of welfare to nationals).

After the empirical analysis of the various national contexts provided for by the different contributors to the book, a final comparison will be held according to the most-similar/most-different systems design. (Taylor-Gooby, Leruth and Chung, 2017, pp. 201-202) The most-similar system design follows a within-regime analysis and examines countries that are similar in their welfare institutional legacies in order to see if there is a path dependency in the policy directions taken. The most-different system design follows a cross-regime analysis to see whether there are policy similarities in countries of different regimes.

The book concludes that despite facing similar challenges in the broader sense, European welfare states have responded differently (Taylor-Gooby, Leruth and Chung, 2017, p.201) and that although the regime approach still captures differences between regimes, they are less clear-cut than before and follow new cross-cutting directions (Taylor-Gooby, Leruth and Chung, 2017, p.212). Therefore, all three theoretical approaches seem to be true. (Taylor-Gooby, Leruth and Chung, 2017, p.214-215) There is convergence in the adaptation of the spending areas of the welfare state to the similar pressures experienced in different countries, such as the resilience of provision for old groups at the detriment of working age groups, the development of dualization and flexibilization of the labour market, the social investment in childcare and the overall move to neo-liberalism and individualism. There are also elements of 
structured diversity in the extent to which different countries enable an expansion of employment through social investment and predistribution. Finally, it can also be argued that there are elements beyond continuity since policies change in a common direction but in ways that vary between countries depending on resistance to or support for change.

The argument is that policy responses have undermined the class alliances that underpinned the post-war welfare state, eroding well-established solidarities and leading to the emergence of new cleavages within European Societies and to the fragmentation of EU politics, namely through the emergence of anti-establishment parties (Taylor-Gooby, Leruth and Chung, 2017, p.14). As a consequence of the erosion of solidarities, it is unclear how far new cleavages are opening and how they will influence welfare state politics (Taylor-Gooby, Leruth and Chung, 2017, p.22).

\section{II.}

After having reviewed the content of the book this section provides a critical reflection on two issues by taking into consideration further literature in the topic.

First, regarding the dominant policy responses. Taylor-Gooby, Leruth and Chung (2017, p.212) argue that the dominant policy responses in the restructuring of the welfare state are austerity and individualisation of responsibility but that neo-keynesian social investment concerned with enhancing competitiveness is also emerging. Therefore, it seems that both austerity cuts and social investment have been implemented to accommodate the welfare state to a more global competitive Europe. In the same way, Hay and Palier (2017, pp.341-342) point to the restructuring of the welfare state from a demand-side (during Keynesian period) to a supply-side oriented conception of the role of welfare (first under neoliberalism and more recently to a partial development of the social investment perspective), i.e. from one that ensures citizen's independence from the market (decommodification) to one that recommodifies citizen's to enhance competitiveness in a global economy.

Second, concerning the way social policies are accommodated to competition. According to Hay and Palier (2017, pp.341-342) the return to market prioritization would be denounced and an alternative and more positive interpretation of the economic context would advocate rechannelling social expenditures towards social investments. Accordingly, (Hay and Palier, 2017, pp.347-348) the challenge would be to improve economic growth while simultaneously attending to the social situation of citizens by investing in human capital formation. However, the turn to social investment has been partial and uneven, with states that shifted to this paradigm before the crisis having overcome the main difficulties and states that relied mainly in consumption for their growth being stuck with depression, unemployment and with little choice other than neoliberal retrenchment and privatisation. This conclusion seems to fit the different policy responses identified by Taylor-Gooby, Leruth and Chung (2017, p.218), namely that Scandinavian countries combine openness with 
strong social investment, that continental Europe's Germany is moving beyond corporatism and is promoting social investment and individual responsibility, and that the Mediterranean countries seek accommodation to liberal openness in various ways, ranging from fightback to social investment.

\section{References}

Hay, C. \& Palier, B. (2017). The Reconfiguration of the Welfare State in Europe. In: D. King and P. Le Galès, eds. 2017. Reconfiguring European States in Crisis. Oxford: Oxford University Press. Ch.17.

Hrast, M. \& Rakar, T. (2017). The Future of the Slovenian Welfare State and Challenges to Solidarity. In: P. Taylor-Gooby, B. Leruth, H. Chung, eds. 2017. After Austerity: welfare state transformation in Europe after the great recession. Oxford: Oxford University Press. Ch.6.

Taylor-Gooby, P., Leruth, B. \& Chung, H. (Eds.) (2017). After Austerity: welfare state transformation in Europe after the great recession. Oxford: Oxford University Press. 